\title{
Modelling bankruptcy prediction models in Slovak companies
}

\author{
Maria Kovacova $^{1, *}$ and Jana Kliestikova $^{1}$ \\ ${ }^{1}$ Department of Economics, Faculty of Operation and Economics of Transport and Communications, \\ University of Zilina, Univerzitna 1, 01026 Zilina, Slovakia
}

\begin{abstract}
An intensive research from academics and practitioners has been provided regarding models for bankruptcy prediction and credit risk management. In spite of numerous researches focusing on forecasting bankruptcy using traditional statistics techniques (e.g. discriminant analysis and logistic regression) and early artificial intelligence models (e.g. artificial neural networks), there is a trend for transition to machine learning models (support vector machines, bagging, boosting, and random forest) to predict bankruptcy one year prior to the event. Comparing the performance of this with unconventional approach with results obtained by discriminant analysis, logistic regression, and neural networks application, it has been found that bagging, boosting, and random forest models outperform the others techniques, and that all prediction accuracy in the testing sample improves when the additional variables are included. On the other side the prediction accuracy of old and well known bankruptcy prediction models is quiet high. Therefore, we aim to analyse these in some way old models on the dataset of Slovak companies to validate their prediction ability in specific conditions. Furthermore, these models will be modelled according to new trends by calculating the influence of elimination of selected variables on the overall prediction ability of these models.
\end{abstract}

Key words: bankruptcy, prediction models, company

\section{Introduction}

Prediction of financial distress is very critical in enterprise risk management, especially for financial institutions. In particular, financial institutions have to develop various risk management models, such as bankruptcy prediction and credit scoring models. For bankruptcy prediction, financial institutions need effective prediction models in order to make appropriate lending decisions. On the other hand, credit scoring models are used for the management of large loan portfolios and/or credit admission evaluation.

Also the 2008 global financial crisis and its aftermath have shown the ability to predict bankruptcy to be a vital management skill. So methodologies used for that purpose should

\footnotetext{
${ }^{*}$ Corresponding author: maria.kovacova@,fpedas.uniza.sk
} 
be as close to reality as possible as bankruptcy prediction is one of the most important business decision-making process [1].

Default of companies as well as default of other subjects represents occasion which happens not only in the market economy. Even with the maximum effort is not possible to avoid bankruptcy. Consequences of these defaults are extensive and have impact not only on the company itself, but it influences all stakeholders and if we look on the company as on the part of market economy it effects all its participants.

The problem of bankruptcy forecasting is one of the most actively studied nowadays among practical and theoretical issues of company management. Assessment of the current financial status and determination of bankruptcy probability are of interest to shareholders, suppliers, creditors and others aiming is to deal with perspective and reliable business partners.

By present, many models of bankruptcy forecasting have been developed, but this area remains still a field of research activity. On the other side little is known about the practical application of existing models mainly because the use of existing models is limited by the conditions in which they are developed. Another question concerns the factors that can be significant for forecasting [2].

This is given by the fact that since different economic environments have various properties that do not allow reusing models and related sets of factors in other conditions. This fact has been also confirmed by comparative studies of models for different countries $[3,4]$.

For developing countries, with the economic structure significantly different from the developed countries this fact is particularly significant [5].

Consequently, respecting the prerequisite that efficient methods can only be applied to companies of the same group in the same economic situation in the period for which the models were originally designed, we aim to analyse, these in some way old models on the dataset of Slovak companies, to validate their prediction ability in specific conditions.

Furthermore, these models will be modelled according to new trends by calculating the influence of elimination of selected variables on the overall prediction ability of these models.

\section{Literature Review}

Currently a huge number of studies are devoted to the issue of bankruptcy prediction. All researches can be divided into two groups. First group of researchers focus their attention on forecasting methodology while second group concentrate on the choice of proper variables providing the highest prediction ability.

Based on the used forecasting methodology can be bankruptcy prediction models divided into three main categories: statistical models, artificial intelligence and theoretical models [6]. Until the end of twenty century the basic prediction methodologies were based on statistical methods, such as the most common discriminant analysis [7, 8, 9], logit [10] and probit $[11,12]$. These statistical methods are quiet popular among researchers and practitioners even nowadays as their prediction ability is relatively high and the way of processing not so difficult.

On the other side in the beginning of 21 st century artificial intelligence expert systems including machine-learning techniques became the primary method for bankruptcy prediction. Mainly artificial neural networks (ANN) were used [13]. Although the prediction ability of ANNs is comparatively higher there are reasonable limitations such as the need to have a great experience in order to select the control parameters properly and difficulties with building the model itself $[14,15]$. 
In addition, some authors have investigated the applicability of other artificial intelligence methods to bankruptcy prediction, for example, the principal component analysis [16, 17], support vector machines [18, 19], decision trees [20, 21], rough sets, [12, 22], data envelopment analysis [23, 24], and others.

Focusing on the second group of researchers concentrating on the choice of proper variables providing the highest prediction ability can be stated that financial indicators are the most popular $[25,21]$.

In addition to these indicators are added other, such as corporate management factors $[26,27]$, environmental factors [28, 29], level of legislation development [30] and so on.

Finally, we can summarize that forecasting models usually include indicators from all of these factors [31]. Additionally can be noted that in spite of the average number of indicators is ten, a large number of indicators doesn't increase the predictive ability of the model [32]. It is important also to note that even though there are more than 500 prediction models worldwide, many of which have shown high predictive ability, they are poorly used in practice and the focus is mainly on developing new ones reflecting specific individual environment.

Therefore, we aim to analyse these in some way old models on the dataset of Slovak companies to validate their prediction ability in specific conditions. Furthermore, these models will be modelled according to new trends by calculating the influence of elimination of selected variables on the overall prediction ability of these models.

\section{Data and Methodology}

For the presented study we have used dataset of annual financial reports of Slovak companies, which were gained through the Register of financial statements, Ministry of Finance of the Slovak Republic. Calculations were provided on the basis of the year 2015.

To validate the prediction ability of selected old models in specific conditions of Slovak environment we had to set criterions to classify company as bankrupt or non-bankrupt. These criterions were set according to Slovak legal system in combination with other significant characteristics respecting specifics of Slovak environment [33, 34].

Based on the given criterions we consider company as bankrupt if:

- negative value of earnings after taxes,

- the value of financial independence indicator is less than 0.04 ,

- the value of current ratio indicator is less than 1 ,

- company has at least two liabilities 30 days after due date from different creditors,

- the total amount of payable and not payable liabilities is higher that the value of company's assets.

According to these specifics we have randomly chosen 768 companies (50\% bankrupt and $50 \%$ non-bankrupt) for which we calculated selected bankruptcy prediction models to validate their prediction ability in specific conditions.

Additionally, these models will be modelled according to new trends by calculating the influence of elimination of selected variables on the overall prediction ability of these models.

To fulfil the aim of the presented study and further calculations we selected bankruptcy prediction models shown in table 1, applied them on the dataset of Slovak companies to validate prediction ability of these models. 


\begin{tabular}{|c|c|c|c|c|c|}
\hline 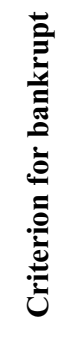 & 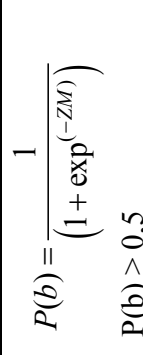 & 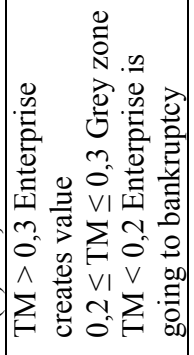 & 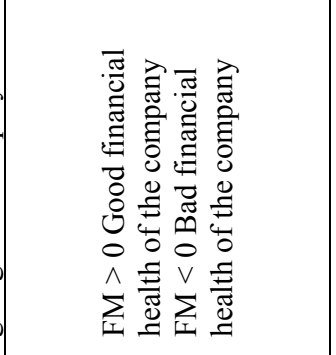 & 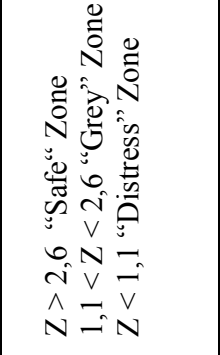 & 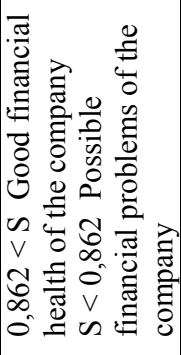 \\
\hline 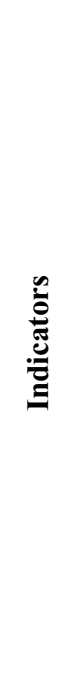 & 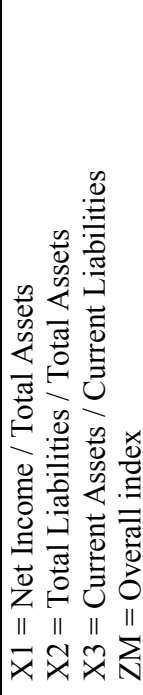 & 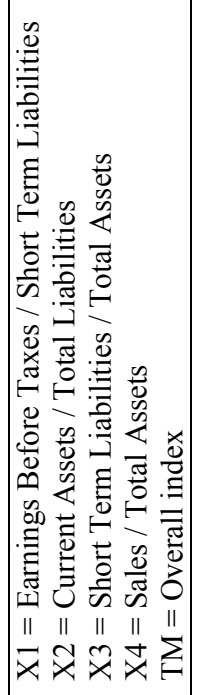 & 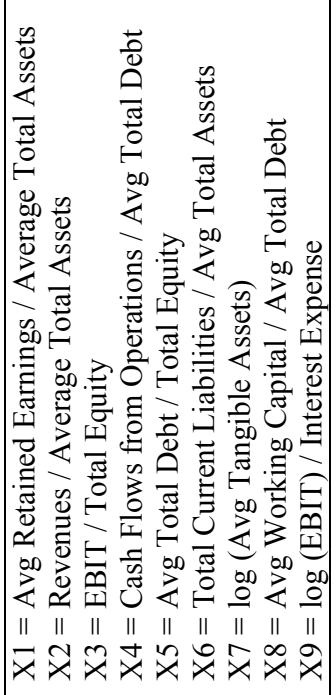 & 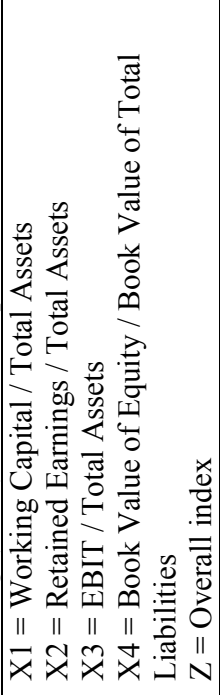 & 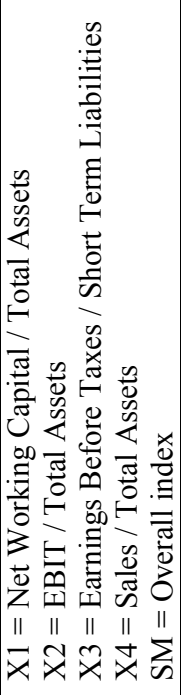 \\
\hline & 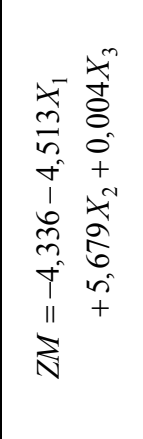 & 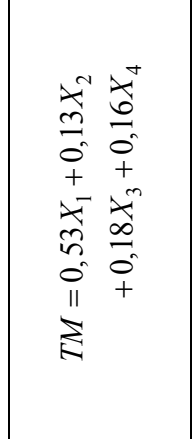 & 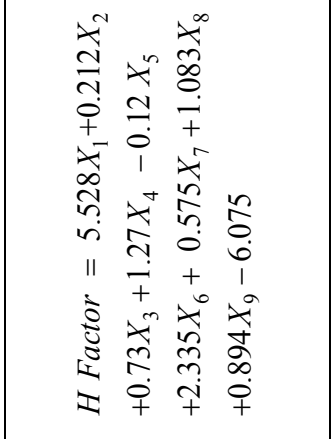 & 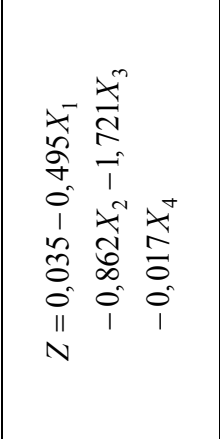 & 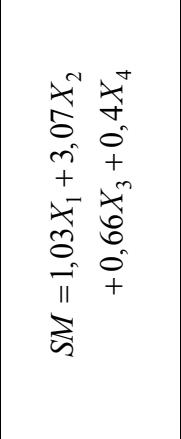 \\
\hline 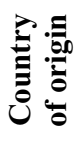 & 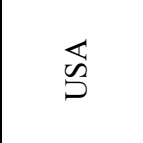 & 光 & 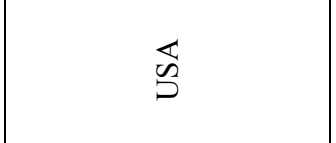 & 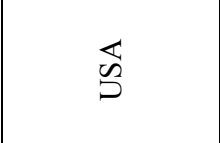 & 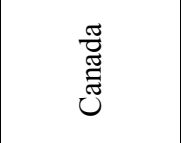 \\
\hline 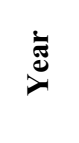 & \begin{tabular}{l}
\multirow{\infty}{*}{} \\
$\stackrel{2}{2}$
\end{tabular} & $\begin{array}{l}\mathscr{\infty} \\
\stackrel{\sigma}{\sigma}\end{array}$ & $\begin{array}{l}\stackrel{+}{\infty} \\
\stackrel{-}{二}\end{array}$ & 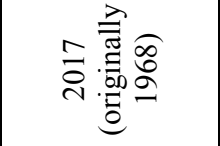 & $\frac{\infty}{\sigma}$ \\
\hline$\stackrel{\grave{\Xi}}{\stackrel{E}{E}}$ & 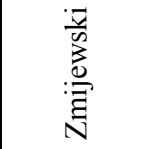 & 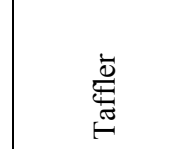 & 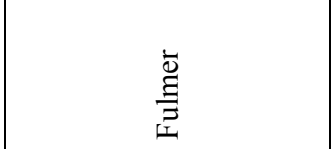 & $\begin{array}{l}\text { 志 } \\
\text { E }\end{array}$ & 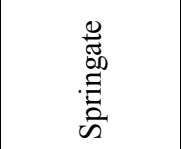 \\
\hline
\end{tabular}


Confusion matrix and receiver operating characteristic curve (ROC) are considered as the most relevant and appropriate tools for the validation of predictive ability of tested models [38].

Table 2. Confusion matrix (Source: self-processed)

\begin{tabular}{|c|c|c|c|c|}
\hline & \multicolumn{2}{|c|}{ Predictive value } & \\
\hline & & 0 (non-bankrupt) & 1 (bankrupt) & \\
\hline \multirow{2}{*}{ Actual value } & 0 (non-bankrupt) & TP & FN & $\mathrm{TP}+\mathrm{FN}$ \\
\hline & 1 (bankrupt) & FP & TN & $\mathrm{FP}+\mathrm{TN}$ \\
\hline & $\mathrm{TP}+\mathrm{FP}$ & $\mathrm{FN}+\mathrm{TN}$ & Total \\
\hline
\end{tabular}

Confusion matrix (see table 2) can be stated as contingency table linking the number of proper and improper company' classification based on the actual and predicted values and indicating following relevant characteristics:

- Type I. error (false positive) - percentage of bankrupt companies predicted by the model as non-bankrupt,

- Type II. error (false negative) - percentage of non-bankrupt companies predicted by the model as bankrupt,

- sensitivity (positive predictive value) - percentage of correct classification of nonbankrupt companies,

- specificity (negative predictive value) - percentage of correct classification of bankrupt companies,

- model accuracy - overall prediction ability of the model according to data set of companies also known as accuracy of prediction model.

\section{Results and Discussion}

To fulfil the given aim of the presented study we have provided calculation and application of five famous bankruptcy prediction models presented in table 1 on the dataset of Slovak companies. Results are shown in following table 3 and table 4.

Based on these results can be assumed that all calculated prediction models have reached about $50 \%$ prediction accuracy on the dataset of Slovak companies. This is given mainly because of the high type I. error in models of Fulmer (62\%), Altman (99\%) and Springate (78\%).

On the other side in models of Zmijewski and Taffler the type I. error and type II. error were similar about $50 \%$. Accoriding to provided calculation we can assume that we haven't found important differences between tested model's ability to predict future bankrupt of the company. 
Table 3. Calculated confusion matrix of chosen models (Source: self-processed)

\begin{tabular}{|c|c|c|c|c|}
\hline \multirow{2}{*}{\multicolumn{2}{|c|}{ Zmijewski model }} & \multicolumn{2}{|c|}{ Predictive value } & \multirow[b]{3}{*}{384} \\
\hline & & \multirow{2}{*}{$\begin{array}{c}0 \text { (non-bankrupt) } \\
201\end{array}$} & \multirow{2}{*}{$\begin{array}{c}1 \text { (bankrupt) } \\
183\end{array}$} & \\
\hline \multirow{2}{*}{ Actual value } & 0 (non-bankrupt) & & & \\
\hline & 1 (bankrupt) & 186 & 198 & 384 \\
\hline & & 387 & 381 & 768 \\
\hline \multirow{2}{*}{\multicolumn{2}{|c|}{ Taffler model }} & \multicolumn{2}{|c|}{ Predictive value } & \\
\hline & & 0 (non-bankrupt) & 1 (bankrupt) & \\
\hline \multirow{2}{*}{ Actual value } & 0 (non-bankrupt) & 231 & 153 & 384 \\
\hline & 1 (bankrupt) & 205 & 179 & 384 \\
\hline & & 436 & 332 & 768 \\
\hline \multirow{2}{*}{\multicolumn{2}{|c|}{ Fulmer model }} & \multicolumn{2}{|c|}{ Predictive value } & \\
\hline & & 0 (non-bankrupt) & 1 (bankrupt) & \\
\hline \multirow{2}{*}{ Actual value } & 0 (non-bankrupt) & 273 & 111 & 384 \\
\hline & 1 (bankrupt) & 237 & 147 & 384 \\
\hline & & 510 & 258 & 768 \\
\hline \multirow{2}{*}{\multicolumn{2}{|c|}{ Altman model }} & \multicolumn{2}{|c|}{ Predictive value } & \\
\hline & & 0 (non-bankrupt) & 1 (bankrupt) & \\
\hline \multirow{2}{*}{ Actual value } & 0 (non-bankrupt) & 375 & 9 & 384 \\
\hline & 1 (bankrupt) & 380 & 4 & 384 \\
\hline & & 755 & 13 & 768 \\
\hline \multirow{2}{*}{\multicolumn{2}{|c|}{ Springate model }} & \multicolumn{2}{|c|}{ Predictive value } & \\
\hline & & 0 (non-bankrupt) & 1 (bankrupt) & \\
\hline \multirow{2}{*}{ Actual value } & 0 (non-bankrupt) & 322 & 62 & 384 \\
\hline & 1 (bankrupt) & 299 & 85 & 384 \\
\hline & & 621 & 147 & 768 \\
\hline
\end{tabular}

Calculations of relevant characteristics regarding assessing tested models are provided in table 4.

Table 4. Calculated characteristics of chosen models (Source: self-processed)

\begin{tabular}{|c|c|c|c|c|c|}
\hline Model & $\begin{array}{c}\text { Zmijewski } \\
\text { model }\end{array}$ & $\begin{array}{c}\text { Taffler } \\
\text { model }\end{array}$ & $\begin{array}{c}\text { Fulmer } \\
\text { model }\end{array}$ & $\begin{array}{c}\text { Altman } \\
\text { model }\end{array}$ & $\begin{array}{c}\text { Springate } \\
\text { model }\end{array}$ \\
\hline Type I. error & 0.4844 & 0.5339 & 0.6172 & 0.9896 & 0.7786 \\
\hline Type II. error & 0.4766 & 0.3984 & 0.2891 & 0.0234 & 0.1615 \\
\hline Sensitivity & 0.5234 & 0.6016 & 0.7109 & 0.9766 & 0.8385 \\
\hline Specificity & 0.5156 & 0.4661 & 0.3828 & 0.0104 & 0.2214 \\
\hline Model accuracy & $51.95 \%$ & $53.39 \%$ & $54.69 \%$ & $49.35 \%$ & $52.99 \%$ \\
\hline
\end{tabular}

Furthermore, we have modelled these models according to new trends by calculating the influence of removal of individual variables on the overall prediction ability of these models. Therefore, we provided new calculations for each model while removing each indicator and testing the new overall prediction ability. The aim was to assess the impact of these removal on the model accuracy, which will serve as a basis for future research. 
Table 5. Calculated new model's accuracies after removal of individual indicators (Source: selfprocessed)

\begin{tabular}{|c|c|c|c|}
\hline Model & Model accuracy & Indicator removed & $\begin{array}{c}\text { New model } \\
\text { accuracy }\end{array}$ \\
\hline \multirow{3}{*}{$\begin{array}{l}\text { Zmijewski } \\
\text { model }\end{array}$} & \multirow{3}{*}{$51,95 \%$} & $\begin{array}{l}\mathrm{X} 1=\text { Net Income } / \text { Total } \\
\text { Assets }\end{array}$ & $51.43 \%$ \\
\hline & & $\begin{array}{l}\text { X2 = Total Liabilities / } \\
\text { Total Assets }\end{array}$ & $50.65 \%$ \\
\hline & & $\begin{array}{l}\text { X3 = Current Assets / } \\
\text { Current Liabilities }\end{array}$ & $52.21 \%$ \\
\hline \multirow{4}{*}{ Taffler model } & \multirow{4}{*}{$53,39 \%$} & $\begin{array}{l}\text { X1 = Earnings Before } \\
\text { Taxes / Short Term } \\
\text { Liabilities }\end{array}$ & $53.65 \%$ \\
\hline & & $\begin{array}{l}\text { X2 = Current Assets / } \\
\text { Total Liabilities }\end{array}$ & $51.95 \%$ \\
\hline & & $\begin{array}{l}\text { X3 = Short Term } \\
\text { Liabilities / Total Assets }\end{array}$ & $52.73 \%$ \\
\hline & & $\mathrm{X} 4=$ Sales $/$ Total Assets & $53.91 \%$ \\
\hline \multirow{9}{*}{ Fulmer model } & \multirow{9}{*}{$54,69 \%$} & $\begin{array}{l}\text { X1 = Avg Retained } \\
\text { Earnings / Average Total } \\
\text { Assets }\end{array}$ & $54.95 \%$ \\
\hline & & $\begin{array}{l}\text { X2 = Revenues / Average } \\
\text { Total Assets }\end{array}$ & $54.95 \%$ \\
\hline & & $\mathrm{X} 3=\mathrm{EBIT} /$ Total Equity & $54.95 \%$ \\
\hline & & $\begin{array}{l}\text { X4 = Cash Flows from } \\
\text { Operations / Avg Total } \\
\text { Debt }\end{array}$ & $54.17 \%$ \\
\hline & & $\begin{array}{l}\text { X5 = Avg Total Debt / } \\
\text { Total Equity }\end{array}$ & $54.43 \%$ \\
\hline & & $\begin{array}{l}\text { X6= Total Current } \\
\text { Liabilities / Avg Total } \\
\text { Assets }\end{array}$ & $52.99 \%$ \\
\hline & & $\begin{array}{l}\text { X7 }=\log (\text { Avg Tangible } \\
\text { Assets) }\end{array}$ & $53.65 \%$ \\
\hline & & $\begin{array}{l}\text { X8 = Avg Working } \\
\text { Capital / Avg Total Debt }\end{array}$ & $52.99 \%$ \\
\hline & & $\begin{array}{l}\mathrm{X} 9=\log (\mathrm{EBIT}) / \text { Interest } \\
\text { Expense }\end{array}$ & $54.04 \%$ \\
\hline \multirow{4}{*}{ Altman model } & \multirow{4}{*}{$49,35 \%$} & $\begin{array}{l}\text { X1 = Working Capital / } \\
\text { Total Assets }\end{array}$ & $49.22 \%$ \\
\hline & & $\begin{array}{l}\text { X2 = Retained Earnings / } \\
\text { Total Assets }\end{array}$ & $49.22 \%$ \\
\hline & & $\mathrm{X} 3=\mathrm{EBIT} /$ Total Assets & $50.00 \%$ \\
\hline & & $\begin{array}{l}\text { X4 = Book Value of } \\
\text { Equity / Book Value of } \\
\text { Total Liabilities }\end{array}$ & $49.35 \%$ \\
\hline \multirow{3}{*}{$\begin{array}{l}\text { Springate } \\
\text { model }\end{array}$} & \multirow{3}{*}{$52,99 \%$} & $\begin{array}{l}\text { X1 = Net Working } \\
\text { Capital / Total Assets }\end{array}$ & $52.21 \%$ \\
\hline & & $\mathrm{X} 2=\mathrm{EBIT} /$ Total Assets & $51.30 \%$ \\
\hline & & $\begin{array}{l}\text { X3 = Earnings Before } \\
\text { Taxes / Short Term }\end{array}$ & $53.52 \%$ \\
\hline
\end{tabular}




\begin{tabular}{|l|l|l|}
\cline { 3 - 3 } & Liabilities & \\
\cline { 3 - 3 } & X4 = Sales / Total Assets & $53.26 \%$ \\
\hline
\end{tabular}

Results of modelling provided in table 5 have shown us that removal of individual indicators of models doesn't lead to significant improvement of their overall prediction accuracy. There are only small differences gained by provided calculations and mainly the removal has led to decrease of ability of the model to predict future bankrupt of the company.

These findings confirmed that there is a need to adjust bankruptcy prediction models to different economic environments. These contrasts cause the limited options to reuse models and related sets of indicators in other conditions. This is highly important also in the case of Slovak Republic. Our calculations have shown that the use of foreign models has led only to $50 \%$ prediction accuracy. Although these models are well known and were constructed in developed countries their applicability in developing countries, with the economic structure significantly different from the developed countries this fact is particularly substantial [5].

Our findings are in strong correlation with findings of other research studies confirming the need to develop specific models for different countries [3]. Additionally also new indicators, not only financial, should be included for forecasting in such surroundings [31].

This limitation was in some way eliminated by designation of a predictive model that can be easily adapted to any new situation, both in terms of model architecture and the indicators used [2].

\section{Conclusion}

In spite of numerous researches focusing on forecasting bankruptcy using not only traditional statistics techniques, but also artificial intelligence models, they are rarely used in practise. This is given mainly by the fact which was confirmed also in the presented study that the prediction ability of the model developed in specific conditions of individual country can't be successfully applied in the conditions of other country or environment.

Therefore, we aim to analyse in some way old models on the dataset of Slovak companies to validate their prediction ability in specific conditions. Results have shown that the prediction accuracy of these models was about $50 \%$, which is quiet low.

Furthermore, these models were modelled according to new trends by calculating the influence of elimination of selected variables on the overall prediction ability of these models. This modelling hadn't led to significant improvement of the overall prediction accuracy of tested models. There were only small differences gained by provided calculations and mainly the removal had led to decrease of ability of the model to predict future bankrupt of the company.

Results obtained in the presented study have confirmed in some way conclusions of previously published researches. However, the issue of bankruptcy prediction is widely spread worldwide for many years and there have been developed numerous models, since nowadays there hasn't been developed any generally accepted bankruptcy prediction model which can be generally applied regardless specific environment of individual countries. 


\section{Acknowledgements}

This work was supported by the Slovak Research and Development Agency under Grant number APVV-14-0841: Comprehensive Prediction Model of the Financial Health of Slovak Companies.

\section{References}

1. E. Kirkos, Assesing methodologies for intelligent bankruptcy prediction. Art. Int. Rev., 43, 83-123 (2015)

2. Y. Zelenkov, E. Fedorova, D. Chekrizov, Two-step classification method based on genetic algorithm for bankruptcy forecasting. Exp. Sys. App., 88, 393-401 (2017)

3. D. Liang, Ch. Tsai, $\mathrm{H}$. $\mathrm{Wu}$, The effect of feature selection on financial distress prediction. Know. Bas. Sys., 73, 289-297 (2015)

4. Y. Peng, G. Wang, G. Kou, Y. Shi, An empirical study of classification algorithm evaluation for financial risk prediction. App. S. Comp, 11(2), 2906-2915 (2011)

5. E. Fedorova, E. Gilenko, S. Dovzhenko, Bankruptcy prediction for Russian companies: Application of combined classifiers. Exp. Sys. App., 40(18), 7285-7293 (2013)

6. M. A. Aziz, H. A. Dar, Predicting corporate bankruptcy: Where we stand? Corp. Gov. Int. J Bus. Soc., 6, 18-33 (2006)

7. E. I. Altman, Financial ratios, discriminant analysis and the prediction of corporate bankruptcy. J Fin., 23(4), 589-609 (1968)

8. R.O. Edmister, Financial ratios as discriminant predictors of small business failure. Journal of Finance, 27(1), 139-140 (1972)

9. G.L.V. Springate, Predicting the possibility of failure in a Canadian firm (Unpublished master's thesis), Simon Fraser University, Canada 42 (1978)

10. J. A. Ohlson, Financial ratios and the probabilistic prediction of bankruptcy. $J$ Acc. Res., 18(1), 109-131 (1980)

11. M.E. Zmijewski, Methodological issues related to the estimation of financial distress prediction models. J. Acc. Res., 22, 59-82 (1984)

12. A.A. Kasgari, M. Divsalar, M.R. Javid, S.J. Ebrahimian, Prediction of bankruptcy Iranian corporations through artificial neural network and Probit-based analyses. Neur. Com. App., 23(3-4), 927-936 (2013)

13. J.L. Bellovary, D.E. Giacomino, M.D. Akers, A review of bankruptcy prediction studies: 1930 to present. J Fin. Edu., 33, 1-42 (2007)

14. N. Gordini, A genetic algorithm approach for SMEs bankruptcy prediction: empirical evidence from Italy. Exp Sys. App., 41(14), 6433-6445 (2014)

15. D. Santos, E. M. Sabourin, P. Maupin, Overfitting cautious selection of classifier ensembles with genetic algorithms. Inf. Fus., 10(2), 150-162 (2009)

16. M. V. Achim, C. Mare, S. N. Borlea, A statistical model of financial risk bankruptcy applied for Romanian manufacturing industry. International Conference on Emerging Markets Queries in Finance and Business, 3, 132-137 (2012)

17. M. Onofrei, D. Lupu, The modelling of forecasting the bankruptcy risk in Romania. Ec. Com. Ec. Cyb. St. Res., 48(3), 197-215 (2014)

18. D. Alaminos, A. DelCastillo, M. A. Fernandez, A global model for bankruptcy prediction. Pl. One, 11(11) (2016) 
19. D. Zhao, C. Y. Huang, Y. Wei, F. H. Yu, M. J. Wang, H. L. Chen, An effective computational model for bankruptcy prediction using kernel extreme learning machine approach. Com. Eco., 49(2), 325-341 (2017)

20. C.F. Tsai, Y.F. Hsu, D.C. Yen, A comparative study of classifier ensembles for bankruptcy prediction. App. S. Com., 24, 977-984 (2014)

21. N, Zieba, S.K. Tomczak, J.M. Tomczak, Ensemble boosted trees with synthetic features generation in application to bankruptcy prediction. Exp. Sys. App., 58, 93-101 (2016)

22. M. Virag, T. Nyitrai. Is there a trade-off between the predictive power and the interpretability of bankruptcy models? The case of the first Hungarian bankruptcy prediction model. Ac. Oec., 64(4), 419-440 (2014)

23. I. M. Premachandra, Y. Chen, J. Watson, DEA as a tool for predicting corporate failure and success: a case of bankruptcy assessment. Om. Int. J Man. Sc., 39(6), 620-626 (2011)

24. M. M. Mousavi, J. Ouenniche, B. Xu, Performance evaluation of bankruptcy prediction models: an orientation-free super-efficiency DEA-based framework. Int. Rev. Fin. An., 42, 64-75 (2015)

25. P. DuJardin, A two-stage classification technique for bankruptcy prediction. Eur. J Op. Res. 254(1), 236-252 (2016)

26. C. Salloum, N. Azoury, Corporate governance and firms in financial distress: evidence from a Middle Eastern country. Int. J Bus. Gov. Eth., 7(1), 1-17 (2012)

27. X. Bredart, Financial distress and corporate governance: the impact of board configuration. Int. Bus. Res., 7(3), 72 (2014)

28. M. Karas, M. Reznakova, To what degree is the accuracy of a bankruptcy prediction model affected by the environment? The case of the Baltic States and the Czech Republic. Pr. Soc. Beh. Sc., 156, 564-568 (2014)

29. V. Delas, E. Nosova, O. Yafinovych, Financial security of enterprises. Pr. Ec. Fin., 27, 248-266 (2015)

30. M. Rowoldt, D. Starke, The role of governments in hostile takeovers - evidence from regulation, anti-takeover provisions and government interventions. Int. Rev. Law Ec., 47, 1-15 (2016)

31. M. H. Tinoco, N. Wilson, Financial distress and bankruptcy prediction among listed companies using accounting, market and macroeconomic variables. Int. Rev. Fin. An., 30, 394-419 (2013)

32. T. Kliestik, J. Majerova, Selected issues of selection of significant variables in the prediction models. Financial management of firms and financial institutions: 10th international scientific conference, 537-543 (2015)

33. V. Bartosova, P. Kral, A methodological framework of financial analysis results objectification in the Slovak Republic. European Proceedings of Social \& Behavioural Sciences, 17, 189-197 (2016)

34. M. Durica, P. Adamko, Verification of MDA bankruptcy prediction models for enterprises in Slovak Republic. 10th international scientific conference International Days of Statistics and Economics, 400-407 (2016)

35. R. J. Taffler, M. Tseung, The audit going-concern in practice. Pr. Acc. Mag., 88, 263269 (1984)

36. J. G. Fulmer, J. E. Moon, T. A. Gavin, M. J. Erwin, A bankruptcy classification model for small firms. J Com. B. Len., 25-37 (1984) 
37. E. I. Altman, M. Iwanicz-Drozdowska, E.K. Laitinen, Financial distress prediction in an international context: a review and empirical analysis of Altman's Z-score model. $J$ Int. Fin. Man. Acc., 28(2), 131-171 (2017)

38. P. Adamko, L. Svabova, Prediction of the risk of bankruptcy of Slovak companies. International Scientific Conference Managing and Modelling of Financial Risks, 15-20 (2016) 
